\title{
The Impact of Thinking Maps on Enthusiasm, Attitude and Learning Style: An Action Research Study of Students in Management Course
}

\author{
Shahibudin Ishak \\ School of Business Management, College of Business, Universiti Utara Malaysia, UUM Sintok, Kedah Darul Aman, Malaysia \\ Email address: \\ shahibudin@uum.edu.my \\ To cite this article: \\ Shahibudin Ishak. The Impact of Thinking Maps on Enthusiasm, Attitude and Learning Style: An Action Research Study of Students in \\ Management Course. Science Journal of Education. Vol. 3, No. 5, 2015, pp. 107-113. doi: 10.11648/j.sjedu.20150305.12
}

\begin{abstract}
Enthusiasm, attitude and learning style are the factors that make students are more eager learners and become active participants in their learning. Little research at higher education level considers Thinking Maps as a tool in teaching and learning. Thus, this action research investigates the impact of Thinking Maps on enthusiasm, attitude and Learning style of student in learning the Principles of Management. The results should assist the lecturer in make teaching is more students centered learning. Eight Thinking Maps were used as the mind mapping maps method to increase students' enthusiasm and change attitude and Learning style. The sampling of eighty students from the same group was chosen for the study. Researcher uses three kinds of instruments in collecting the data, namely; lecturer's observations, reflection and pre and post intervention survey were used to record changes in enthusiasm, attitude and style for learning during study period. The result shows the students express their tendency to use Thinking Maps method in learning. Additionally, the students increase their enthusiast in learning principle of management but their attitude and learning style not much change.
\end{abstract}

Keywords: Thinking Maps, Enthusiasm, I-Think, Action Research, Education Management

\section{Introduction}

\subsection{Past Teaching \& Learning Reflection}

In all educational levels, learning involves an extremely complex human process. Educators will face a common problem in classroom where teachers teach but students do not learn. During my twenty-four years of teaching in school level, I have used many strategies to enhance student learning. Students is hoped to be actively involved in their learning. Interested and enthusiastic students are more willing learners and become active participants in their own instruction. As children become more actively beginning in their learning, they develop interest and enthusiasm for the content and for acquiring new knowledge.

Teaching is mainly an effort of knowledge transfer in classrooms. Current practice during classroom lessons in this course, I found that majority of the student did not taking any note. They just watching and listening and have no note book to take any notes in enhance the understanding of learning. The attitude did not record any notes as reason boredom arise in the classroom.In the presentation session during lecture, it was found that students have problems to master their presentation. This leads the students not being active and just focused presentation materials in the computer. This common problem in teaching management to students has been limited preparation, motivation and interest of students towards the subject. Discussion classes in English also lead the class not lively and stress for some student. Researchers make a conclusion that enthusiasm, attitude and learning style become key factors that need to be addressed to help students answer examination questions. Therefore, students methods of learning was an aspect that I wish to improve during this study.

\subsection{Initial Finding}

Teaching and learning managements in tertiary education is an issue that concerns researchers who teach undergraduate courses. The researcher concerned with how to change classroom environment so that the students do not passively receive information but actively construct their own knowledge. This study is derived from the reflection process conducted by researchers in identifying the strengths, 
weaknesses and problems encountered in my teaching and learning. The researcher has performed the initial data collection process for and constructs the problem faced by students. This process is implemented in the form of observations, document analysis and questionnaire. Based on the data obtained, the researcher has concluded that the main problems faced by a number of students, were difficulty remembering and understanding the concept of management. Thus, student enthusiasm to learn seems very low. One of its possible causes may be the method of taking note during lecture or making presentation during class was boring.

Since the first week, personal background and early life of the students were collected. It was found that a majority of them are the new students and some senior students. They will act passively when you are in class. I have also observed the teaching and learning process carried out in class during the week. I found that some students are less active in producing ideas when prompted. It may be caused by the class have conducted fully in English Language. This situation is different when English is used during discussion. I have observed and made notes as to how the students were working and their reactions to class. These observations were guided by several questions: What problems are the students encountering as they work on their multimedia presentations? Are the students having problems with content? Are there problems in taking note during lecture? These observations and notes were useful in making sense of any fluctuations I found in the end-of-study student surveys. I had interviewed several students to ask questions about their interests. I have chosen 10 students of class to be interviewed. Each student selected consists of different categories, namely Malay, Chinese, Indian and foreign. Results obtained only 3 students who sometimes love management, 3 and 4 people dislike management.

The findings about students ' enthusiasm at an early stage have rates that, on the average, only $15 \%$ of students interested in management compared to other subject, majorly students which is $40 \%$ state they are less interested in management. $15 \%$ students expressed the course is entertaining but 26.7 stated that management course is boring. Half of the students (48\%) said they were happy to learn on their own. A total of $61 \%$ of students, students agree that group learning is better compared learn on their own. $15 \%$ students remain vague about their learning style. A total of $88 \%$ said much needs to be remembered and masterly in management theme. The majority of the students said that very difficult to score A and difficult to pass.

From this initial reflection, I made the conclusion that the root cause of this problem was students learning style and course content. Through this study I hoped to find that Thinking Maps would be the method that my students needed to acquire new knowledge, develop new concepts, and express strong understanding. Through the integration of Thinking Maps, I hoped to tap the enthusiasm of my students towards learning science and make them active participants in their own instruction.

\subsection{Thinking Maps}

Thinking Maps is mapping maps that innovate thinking or thinking that fosters innovation thinking skills; cultivate a culture of lifelong learning; skilled in problem solving and able to generate creative solutions among students [1].Thinking Maps history started with Dr. Albert Upton, a professor at Whittier College, California, writes Design for Thinking, a theoretical text defining fundamental thinking processes based on semantics, cognitive psychology, and problem-solving [2]. Then, Innovative Sciences, Inc. (ISI) founded by Charles Adams uses Upton's work to help identify how to improve the thinking and problem-solving abilities of the workforce. Led by Col. Mike Gilrod, ISI thinking skills programs are introduced in numerous schools in United State. In 1988, Dr. David Hyerle creates Thinking Maps. In 1994, the Innovative Sciences, Inc. becomes Thinking Maps, Inc. Thousands of schools and districts across the United States have received in-depth training and follow-up using Thinking Maps. Thinking Maps are also utilized internationally such as, in Canada, the United Kingdom, Australia, New Zealand, Ethiopia, and South Africa [8].

Thinking Maps as a set of graphic organizer techniques used in primary and secondary education in Malaysia since 2005 [1]. They are supposed to provide a common visual language to information structure, often employed when students take notes. Thinking Maps are visual tools for learning, and include eight visual patterns each linked to a specific cognitive process. Visualizing thinking allows students to have a concrete image of abstract thoughts. Visual representations enhance the brain's natural ability to detect and construct meaningful patterns. Thinking Maps reduce anxiety by providing familiar visual patterns for thinking and working with complex ideas and situations. Teachers may apply Thinking Maps in all content areas and all grade levels. Thinking Maps are eight specific visual patterns [2]. The eight map types are: Circle Map used for defining in context; Bubble Map used for describing with adjectives; Flow Map used for sequencing and ordering events; Brace Map used for identifying part/whole relationships; Tree Map used for classifying or grouping; Double Bubble Map used for comparing and contrasting; Multi-flow map; used for analyzing causes and effects; and Bridge map used for illustrating analogies.

\section{Focus of the Study}

Diversity of teaching strategies is necessary to improve student achievement [9]. Teachers need to apply the approaches, methods, and techniques for attracting students to follow the teaching and learning in class. Teaching and learning environment that integrates elements of multiple intelligences are able to develop scientific attitudes and values [3]. The premise of this study is graphics and images will be able to stimulate thinking, facilitate understanding and strengthen student retention [4]. 
Issues that are the focus of this study is learning strategies to make students become more enthusiasm and change their attitude and style in learning by encouraging them to become active and doing a lot of thinking [10] . Previous studies show [1] that the level of thinking skills among teachers and students in Malaysia is very low. I-Think programme proposed by Malaysia Ministry of Education is innovative ideas that using Thinking Maps based on Bloom's Taxonomy [5]. It aims to enhance and develop thinking skills among students towards producing students who innovative. Through use of Thinking Maps, students are more confident and active in class and become more student-centered activities. I-Think Programme proposed by MOE is one of the transforming power of education to foster thinking skills among students in Malaysia. Thinking Maps method are becoming popular in school classrooms ion Malaysia, but there is little study at higher learning institutions. This study investigated whether Thinking Maps would help my students as a method needed to acquire new knowledge, develop new concepts, and express strong understanding. Through the integration of Thinking Maps and computer technology, I hoped to tap the enthusiasm of my students towards learning management and make them active participants in their learning. Research shows that using the eight Thinking Maps promote metacognition and continuous cognitive development for students across their academic careers, as well as adds an artistic and kinesthetic component for students who learn effectively with that specific multiple intelligence [6].

\section{Objective of the Study}

\subsection{The Main Objective}

The main objective of this study was to determine whether Thinking Maps methods introduced would enhance enthusiasm, attitude and learning style of students. Thus, this research was carried out:

1. To determine the impact of Thinking maps on enthusiasm, attitude and learning style of the students in management.

2. To determine acceptance level of the use of thinking maps by the student in learning management.

\subsection{Research Questions}

Two questions were addressed in this study.

First, did using Thinking Maps will increase their enthusiasm, change the attitude and style in learning as they did in a traditional classroom setting?

Second, did students accept Thinking Maps as their method of learning in classroom setting?

\section{Methodology for Action Research}

This study was quasi-experimental design where a group pre-test and post-test adopted. Students were pretested on enthusiasm, attitude and learning style before intervention and then post tested after it. Differences between the two administrations were evaluated. The research design for this research was Action Research. During the research, interventions using Thinking Maps were made consistently. The students have the opportunities to use Thinking Maps during group discussion and use the maps during presentations.

\subsection{Target Group}

The study took place in a Principle of management classroom of UUM and lasted for 14 weeks. The participants in this study were students enrolled in Principles of Management course in semester 1 2014. A sample of 80 students from group $\mathrm{C}$ was selected from population of 28 group taking principles of management course. The age group range between 20 to 25 years of age. Majority of the students were in the first semester. The students met as a class with lecturer twice a week for 90 minutes each for a total three hours per week. Most of the students were able to talk and write in proper English.

\subsection{Course Background}

Principles of Management is a comprehensive introductory course on the management process, with particular emphasis on the skills, competencies, techniques and knowledge needed to successfully manage an organization This course investigates how organizations develop and continuously maintain competitive advantage within a changing business environment influenced by political, economic, social, technological, legal and environmental factors. The course content is organized around: planning, organizing, leading and control [POLC] for systematic understanding of management. In addition students are also exposed to certain techniques towards efficient management as well as evaluating the pros and cons raised by task and role management of the present and the future.

\subsection{Data Collection Procedure and Analysis}

This research was based on Kemmis and McTaggart Action Research Model [7], which suggests a four-step of action research. Action research is combines a cycle of identifying a problem, planning an intervention, implementing the intervention, evaluating the outcome [11]. Quantitative and qualitative data were collected for this study. My data was generated by comparing these students' attitudes toward learning management at the beginning of the semester, during my lecture, and at the end of the learning period. The students' attitudes and reactions were documented by my own observations. In the process of study, three types of assessment tools were used by researchers to obtain research data, namely test (Pre-test and post-test), form observations and Questionnaires at the end of the learning session, where each instruments measure different business. Collecting data from three sources allowed for triangulation of the findings in this study. Data triangulation helped reduce the likelihood of error in the findings when 
similar results are reported from two or more of the sources.

\subsubsection{Interview}

In this study, I interviewed 10 respondents in the Group C BPMN 1013. In this interview, the questions raised are related to the effectiveness of actions to be implemented. The interview was made to get feedback from students about the effectiveness of teaching and learning carried out and the advantages and disadvantages of activity. Suggestions from the respondents in order to improve their performance in the future were obtained. Conclusion was made based on the findings of the interviews. Examples of questions in the interview sessions are as set out in: Are you interested in the subject of the Introduction of management? Are you feels management is hard to pass with distinction?

\subsubsection{Observations}

Direct observation is performed five times so that researchers are able to observe and identify the respondent's behavior during the teaching took place. The main focus of this observation is to look at the behavior of the respondents indicate they are interested in continuing learning. The form of observations carried out is structured observation where researchers record observations based on the criteria set out in the observation form. There are four key themes observed include enthusiasm; passive behavior, disciplinary problems and involvement each have two fractions aspects [12]. To all these aspects relate to enthusiasm of learning.

\subsubsection{Survey}

Researchers using two sets of questions for Pre-Test and Post-Test. Pre-test given before the study started which aims to get an overview about the enthusiasm existing students about management. Post - test given to students administered upon completion of all of the five session of teaching. Questions for post-test are equivalent to the previously given Pre-test. Students were asked to rate their answers to each question using a scale of 1 to 5 . The scale was represented by (1) strongly disagree response, (2) Disagree response, (3) indifference, (4) Agree response, and (5) Strongly agree response. During survey was carried out, researchers first read and explain each questionnaire item and scale to the respondent. Researchers provide thorough descriptions of each item in order to avoid confusion among the respondents. Researchers also reminded the respondent to answer the questionnaire with honest and transparent. Next, researchers do analysis of test data to see change in the scores for the group underwent the process of teaching and learning using these methods. The increase scores the students Illustrates, show that the student increased interest in learning and change their attitude and learning style.

Researchers also circulate a questionnaire to get the reaction of the respondents in relation to the method undertaken. The questionnaire was provided to the respondent in the form of closed questions Scale Likert where students should provide scale (1 to 5) for each item of the questionnaire. Questions for the questionnaire were very closely related studies objective. Sample of the items such as the method will create a conducive learning environment that is fun and entertaining, easy to understand. Based on the findings of the survey, researchers were able to conclude whether the use of the method Thinking Maps in learning create a conducive learning environment that is fun and entertaining.

\section{Action Research Implementations}

\subsection{Intervention Action}

Once problems are identified, researchers planed an action as a treatment to the problem that being the main focus. Researchers start preparing the objective of the study, forming research questions, the importance of research, literature references, the target group research, research tools and plan of action. The main focus of this study is to improve the enthusiasm, attitude and style of learning, using Thinking maps. Researchers have explained how to use the Thinking Maps with sample of maps. The students were divided into 20 groups of 4 in a group. In this study, researchers have conducted five sessions of teaching and learning using Thinking Maps method. Research tools that been used was Pre- Test and Post-Test, structured observation and survey. The problem of students who are less interested in management has caused many problems arise during the session of learning and teaching. Therefore, I have chosen teaching approach using Thinking maps with hopes of reaching the objective to increase the interest and motivation and thus improve the performance of the subjects

Researchers conducted five times research \& development sessions as follows:

Activity 1: Researchers show diagrams Thinking Maps via Power Point. The Researchers introduced the eight Thinking Maps. The Researchers explain each map in detail with examples. At the same time, I will also provide notes about Thinking Maps.

Activity 2: During each session of learning and teaching, I will emphasize the use Thinking Maps. The respondent stated the note in the form of Thinking Maps and make presentation in group discussion session.

Activity 3: During these five teaching and learning session, the researchers made observation based on the observation form. This is to see students learning interest along teaching and learning session.

Activity 4: Next, when all five sessions of the teaching and learning completed, researchers distribute Tests to answer by respondents. Questions for the post-test is same as Pre-test. This is to see the level of interest of students in learning.

Activity 5: The final step is to distribute the questionnaire to every respondent. The aim to see whether students enjoy and entertained over methods of teaching and learning carried out.

At this stage, researchers record and analyze all the data collected. The pre Test and Post Test was analyzed using SPSS. Comparison of the test results of pre and Post Test recorded in the form of tables and graphs. The differences 
mean value test displayed. For observation, the researchers noted the observation about what goes on in the classroom during the process of teaching and learning takes place based on the aspects set out in the form of observation. The last process is monitoring. It aims to look at the effectiveness of the methods and actions that have been carried out and monitor the extent to which it can solve problems faced. If the decision is favorable, so the researchers can start the cycle again. This action research cycle can occur on an ongoing basis whether focuses the same problem or other problems.

\subsection{Assessment}

After almost 10 weeks doing action research, I have made my observations during the sessions of learning and teaching, interview some students at random, and distribute the questionnaire.

\subsubsection{Observation}

After learning activities using Thinking Maps was done, students were told to discuss the Group's assignment and make group presentation. The result is overwhelming. From my observation, students provide full focus during the process of learning takes place. Students showed great interest in and willing to listen and pay attention to teachers' explanations. Learning becomes more fun. Students demonstrate a very high level of cooperation to ensure the success of teamwork provided. Students also work together to get the answers right. This activity shows students prefer activities. Students become active and very focus and not dreaming during learning. The involvement of students in answering the questions was on a voluntary basis. This make students encourage other partners to learn. There were no disciplinary problems during the process of learning. From the results of the observation, the researcher concluded that Thinking Maps method improved students' enthusiasm in learning.

\subsubsection{Interviews}

I have interviewed the students that have been questioned at the first stage of the study. Majority of them expressed that they were very interested, happy and fun session learning and teaching management. Furthermore there were students who requested that I continue to teach using Thinking maps. As a result this interview clearly I have succeeded in attracting their interest in attending lessons and teaching. Enthusiasm for learning science was also reflected in student comments during and after the study. In the following, some of participant responses to the interview questions are presented below.

"It's a creative way to present the knowledge."

"It's a lot more fun working on maps."

"I think anyone could benefit from presentation."

"I've enjoyed doing the presentation"

"It was a fun learning experience."

"Taking note using traditional way gets boring, but Thinking maps more easy method."
"There is so much you can memorize the ... that you just cannot from normal note"

"Thinking Maps make learning fun."

"I find it very interesting to work on Thinking Maps. It makes me think a lot."

"It made me enjoy looking up information for my presentation."

Results from interviews with ten participants who did activities using Thinking Maps, I found that Thinking Maps useful and make learning and teaching more easily, enjoy and entertains. Overall this comments indicated that students thought that Thinking Maps is good and beneficial learning process. This information is act as a positive feedback to improve my teaching method as lecturer.

\subsubsection{Survey}

I had given the questionnaire to each of the student to be completed at week fourteen. This questionnaire will reveal the extent to which their enthusiasm, attitudes and towards learning management once taught by me using Thinking maps.

In Table 1 the result summarizes the students' responses to the survey given to the class at the early and at the end of the teaching and learning. It shows the average agree and mean pre-and post-for overall dimension of the study. The mean pre-test score for survey was 3.04, while the mean post-test score was 3.21 , for a .017 increase.

Students' Enthusiasm: Overall, the study shows that there are trends of increased enthusiasm in students to study management after having introduced methods of Thinking Maps. The students become more interested in management subject compare to other subject increased by $10 \%$, more joy (increase 10\%) and class become entertain (increase 16\%). The intervention has been proved to be significantly increasing the learning enthusiasm in management.

Students' Learning Styles: Most of the students had much not changed their stand against learning styles that they love. Students are not interested learning in groups. But overall, the pre-and post-study attitudinal surveys show a change of style for learning management. In the pre-study survey, $49 \%$ of the students were prefer to individual style, but the poststudy survey showed 52\% after Thinking methods introduced. On the pre-study survey, most students (76\%) and increase to $78 \%$ after went through the Thinking Maps process. When the students were asked how they understand the subject, they show a decrease in understand the content if study in group. On the pre-study survey, $67 \%$ of the students were learn more about learning management, but decrease to $55 \%$ of the students were on the post-study survey.

Students' Attitude towards Learning Session: As shown in Table 1, students had not much changed their negative perception of management once they underwent the learning process. They still regard management as burden, much to be remembered difficult and hard to score. Thus this study shows that Thinking Maps method not much changes their attitude in learning. 
Table 1. The pre-and post-study attitudinal surveys.

\begin{tabular}{|c|c|c|c|c|c|}
\hline CONSTRUCTS & ITEM (S) & Agree \% & Mean pre-study & Agree \% & Mean post-study \\
\hline \multirow{3}{*}{ Enthusiasm } & I'm more interested in studying the other subject (negative). & 15 & 2.48 & 25 & 3.02 \\
\hline & A principle of management course is boring (negative). & 27 & 2.92 & 37 & 3.21 \\
\hline & Principles of management course is entertaining & 15 & 2.81 & 30 & 3.15 \\
\hline \multirow{4}{*}{ Learning style } & I can understand the management subject if I learn in group & 61 & 3.71 & 50 & 3.37 \\
\hline & I prefer to learn on my own. & 49 & 3.40 & 52 & 3.48 \\
\hline & The more I learn if I study in a group. & 67 & 4.40 & 55 & 3.55 \\
\hline & In class, I make things better when I do it myself. & 24 & 2.95 & 22 & 2.87 \\
\hline \multirow{4}{*}{$\begin{array}{l}\text { Attitude } \\
\text { toward } \\
\text { management } \\
\text { subject }\end{array}$} & $\begin{array}{l}\text { Too many answers and difficult to determine the correct answer } \\
\text { (negative). }\end{array}$ & 81 & 4.08 & 70 & 3.81 \\
\hline & $\begin{array}{l}\text { I think it is very difficult to understand the terms of management } \\
\text { (negative). }\end{array}$ & 20 & 2.67 & 18 & 2.67 \\
\hline & Principles of management course are easy to pass & 18 & 3.19 & 30 & 3.07 \\
\hline & Much needs to be remembered during the learning and teaching & 88 & 4.55 & 80 & 4.07 \\
\hline
\end{tabular}

\subsubsection{The Acceptance of Students with the Use of Thinking Maps}

The second objective of the study is whether the use of Thinking Maps method in management course accepted by students. This objective is measured based on the survey distributed (Appendix B) at the end of semester. The data obtained from the questionnaire were analyzed using the mean. The mean Students' acceptance towards using Thinking Maps are presented in Table 2. The means of total acceptance of students toward using Thinking Maps is 3.82. Thus most of the students agree that Thinking Maps method is more useful (52\%), eager to learn $(65 \%)$, not troublesome (41\%), fun and easy (57\%), and efficient (63\%).

\section{Research Reflection}

\subsection{Enhance the Interest of Students in Learning Management}

The first objective of the study was to raise the interest of students in learning management is measured based on a structured observation to the behavior of the respondent. There are some aspects observed by researchers throughout study. It aims to see changes in behavior that reflects the interest of pupils when undergoing learning using Thinking maps. The findings of survey shows that the method of Thinking Maps have been able to increase interest in learning the management, as a method to take note and to present the results of group work.

\subsection{Positive Impact on Students' Achievement in the Course of Principle of Management}

Based on quiz scores that were carried out, students can master the course contents. The uses of Thinking Maps give a new dimension to the management learning. Based on the findings of the study, it was found that the achievement of students can be upgraded. Lecturers advised to use Thinking Maps during the teaching and learning for creating a fun atmosphere and consequently improving the students' achievement.

Table 2. Students' Acceptance towards Using Thinking Maps.

\begin{tabular}{llll}
\hline BILL & ITEM (S) & Agree \% & Mean \\
\hline 1 & Teaching using Thinking Maps makes me more eager to learn and succeed in management subject & 65 & 4.07 \\
2 & I love to attend lecture in management subjects using Thinking Maps. & 63 & 3.97 \\
3 & Sometimes the use of Thinking Maps troublesome me to study management subjects. (-ve) & 41 & 3.42 \\
4 & Each student must know how to use Thinking Maps in their studies & 61 & 3.93 \\
5 & Thinking Maps is less useful in the learning process (-ve) & 52 & 3.53 \\
6 & Thinking Maps make learning become fun, easy and realistic & 57 & 3.87 \\
7 & I can quite mastery of concepts and facts on the subject of management using Thinking Maps & 63 & 3.92 \\
8 & I like to make notes using Thinking Map & 49 & 3.63 \\
9 & Teaching using Thinking Maps is more efficient & 63 & 3.98 \\
10 & I easily remember facts on the subject of management with the use of Thinking Maps in the process of & 67 & 3.90 \\
& teaching and learning & & 3.82 \\
\hline
\end{tabular}

\subsection{Changes the Behavior of the Students}

The use of method of Thinking Maps proved to be not only to increase the interest to learn, but at the same time can reduce the passive behavior as well as be able to minimize discipline problem among the students. In addition, the method made the learning more fun and entertaining. This is proved by the findings of the questionnaire indicating that respondent using Thinking Maps feel more entertained and fun. 


\subsection{Researcher Act of Reflection}

From the findings, the intervention using Thinking Maps has been proved in enhancing the enthusiasm of the student to learn management. The research finding can be beneficial for others and It would be enjoyable and beneficial for those teachers who have direct contact with the students. According to the empirical observations of the action research to get the maximum effect of the teaching and learning process, it is important for a teacher to attract students' attention. This is because, when students learn in an atmosphere of enjoyment, in addition to activities available in line with their interest, their motivation for learning will increase. Motivation and interest in learning will drive success in their studies. Teaching methods that re creative and fun like Thinking Maps method can be convincing students to learn, even proven effective to help and strengthen their understanding and mastery the management concepts.

\section{Agenda for the Future}

The results of this study support the notion that the level of enthusiasm for learning management was increase through the inclusion of Thinking Maps method. Management studies classes could practice Thinking Maps during learning in class as a method to take note and make presentations.

Overall, the studies that used Thinking Maps as a tool for learning will have positive impact in their study. However, there are some aspects of the necessary improvements in this study. First, increase the number of respondents so that the findings are more accurate and second applied the Thinking Maps method in other subjects.

I found Thinking maps is a useful tool in enhancing enthusiasm and attitude of the student for learning. The proposed action to the next action research cycle is integrating method of Thinking Maps of activity the group uses along with the computer, in line with the current education that emphasizes the use of information and communication technology. The research finding can be beneficial for other lecturer and provides a method they should adapted to their teaching method. Thinking Maps method is applicable at higher levels of education.

\section{References}

[1] Bahagian Perancangan dan Penyelidikan Pendidikan, Kementerian Pelajaran Malaysia. (2005). Manual Kajian Tindakan. Kuala Lumpur: BPPPDP, KPM.

[2] Thinking Maps, Inc. (2011). Thinking Maps. Retrieved Dicember 29, 2014, from http://www.thinkingmaps.com.

[3] Ikhsan Othman, Rohizani Yaakub. (2010). Aplikasi Teori Kecerdasan Pelbagai dalam Pelaksanaan Kurikulum. Asia Pasific Journal of Educators and Education. Vol.25: 21-32.

[4] Yahya Othman, Azmey Haji Othman. (2012). Keberkesanan Penggunaan Peta Minda dalam Pengajaran dan Pembelajaran Karangan Argumentatif di Sebuah Sekolah Menengah Arab di Negara Brunei Darussalam. Jurnal Pendidikan Bahasa Melayu. Vol.2, Bil. 2: 32-45.

[5] Abu Bakar Nordin. (2013). Kurikulum Ke Arah Penghasilan Kemahiran Berfikiran Kritis, Kreatif dan Inovatif. Jurnal Kurikulum dan Pengajaran Asia Pasifik. Bil 1. Isu 1.

[6] Hyerle, D. (2011). Student successes with Thinking Maps, Second edition. Thousand Oaks: Corwin Press.

[7] Kemmis, S. \& McTaggart, R. (1988). The action research planner. Geelong, Victoria, Australia: Deakin University Press.

[8] Hall, G. E., \& Hord, S. M. (2006). Implementing Change; Pattern, Principles and Patholes. United States of America: Allyn \& Bacon.

[9] Fullan, M. (2007). The new meaning of educational change. 4th Edition. New York: Teacher's College Press.

[10] Oliva, P. F. (2005). Developing the curriculum. New Jersey: Pearson Education.

[11] McNiff, J. (1988). Action Research: Principles and Practice. London: Routledge.

[12] Coughlan, P. \& Coghlan, D. (2002). Action research for operations management. International Journal of Operations and Production Management, Vol. 22, No. 2, 220 - 40.

[13] Clem Adelman. (1993). Kurt Lewin and the Origins of Action Research. United Kingdom: University of Reading.

[14] Stringer, E. T. (1999). Action research. $2^{\text {nd }}$ Ed. Thousand Oaks, CA: Sage. 